\title{
A partial study of vertical distribution of conventional no-till seeders and spatial variability of seed depth placement of maize in the Alentejo region, Portugal
}

\author{
L. A. Conceição ${ }^{1} \cdot$ P. Barreiro ${ }^{2} \cdot$ S. Dias $^{1} \cdot$ M. Garrido ${ }^{2}$. \\ C. Valero ${ }^{2} \cdot$ J. R. Marques da Silva ${ }^{3}$
}

\begin{abstract}
The requirements for a good stand in a no-till field are the same as those for conventional planting as well as added field and machinery management. Among the various factors that contribute towards producing a successful maize crop, seed depth placement is a key determinant. Although most no-till planters on the market work well under good soil and residue conditions, adjustments and even modifications are frequently needed when working with compacted or wet soils or with heavy residues. The main objective of this study, carried out in 2010, 2011 and 2012, was to evaluate the vertical distribution and spatial variability of seed depth placement in a maize crop under no-till conditions, using precision farming technologies and conventional no-till seeders. The results obtained indicate that the seed depth placement was affected by soil moisture content and forward speed. The seed depth placement was negatively correlated with soil resistance and seeding depth had a significant impact on mean emergence time and the percentage of emerged plants. Shallow average depth values and high coefficients of variation suggest a need for improvements in controlling the seeders' sowing depth mechanism or more accurate calibration by operators in the field.
\end{abstract}




\section{Introduction}

Estimates based on the European Commission's Pan-European Soil Erosion Risk Assessment Model (Kirkby et al. 2004) indicate that northern Portugal and western Spain are among the regions with the highest risk of soil erosion by water. Although conservation tillage methods are being increasingly adopted, according to the European Environment Agency, in Spain and Portugal, conservation tillage was used on only $20 \%$ of available arable land in 2005 (Piorr 2011).

According to (Derpsh et al. 2010), no-tillage or zero tillage, which is applied globally on over 100 Mha, under very diverse climatic and soil conditions, is a farming system in which seeds are directly deposited into untilled soils that retain the previous crop residues. Lower labour requirements, less energy consumption and lower machinery costs, as well as other economic and environmental benefits, are associated with no-till farming, compared to conventional tillage systems and other types of conservation tillage (Uri 2000; Tabatabaeefar et al. 2009). Compared to conventional tillage, fuel consumption and therefore total energy savings per hectare are $10 \%$ with reduced tillage and $32 \%$ with notillage, due to fewer mechanical operations and the higher working capacity of the machines (Borin et al. 1997).

Studies on the combination of no-till and the use of different crops and amounts of residues and their management on the evolution of organic matter in soil suggest that returning cereal residues instead of removing them or grazing in combination with no-till for crop establishment can contribute significantly towards improving the low organic matter levels found in soil in Mediterranean environments (Madejón et al. 2009; Basch et al. 2008). It can also promote an appropriate ratio between macro and micro pore water retention and thus it has a direct and indirect effect on crop stands, (Carvalho and Basch 1999; Govaerts et al. 2009), and the total soil carbon content (Basso et al. 2011), thereby reducing $\mathrm{CO}_{2}$ (Ussiri and $\mathrm{Lal} 2009$ ), $\mathrm{N}_{2} \mathrm{O}$ and $\mathrm{CH}_{4}$ (Ussiri et al. 2009) emissions and hence improving the physical and chemical properties of the soil (Sá 2004).

It seems increasingly likely that no-till seeding and the associated conservation of surface residues will become the standard farming practice in Mediterranean countries, because of better economics and improved soil and water conservation (Soane et al. 2012). Since the 1980 s, different experiments with soil tillage systems have been conducted for the major cereal crops, such as grain cereals, pasture, forage, sunflower and irrigated maize, cultivated in the Alentejo region, in Portugal. Except for sunflower, results have shown no yield reduction when compared with direct seeding. In Mediterranean regions, no-tillage also represents cost and time savings, because irrigated systems have made it possible for two harvests per year (Carvalho and Basch 1994).

In 2013, no-tillage seeding was practised on 32000 ha in Portugal (FAO aquastat 2015) and maize crop is the main irrigated crop under this practice (INE 2011). However, limitations on the implementation of direct drilling systems are known, due to the variability of soil texture and crop residue management, making uniform seed spreading and, as a result, uniform establishment and emergence more difficult.

According to the Portuguese Environment Agency's atlas (SROA 1978), the Alentejo region presents a wide diversity of geology and field soil composition with a predominance of luvisoils, cambisoils and litosoils. The physical properties of the soil can be greatly influenced in a Koppen-Geijer Csa climate (Kottek et al. 2006), characterized by dry hot summers and cold wet winters. Major constraints on production in these soils include the low carbon nitrogen ratio due to a very active mineralisation process, low organic matter 
content and low average $\mathrm{pH}$ (Carvalho 2003). The possibility of flooding, soil compaction and difficulty in mechanical operations due to high soil cohesion and weed invasion may affect seeder performance and so it is important to choose the right seeder furrow opener. Soil texture affects moisture retention of the profile, depending on the season of the year. In winter, rainy periods increase soil cohesion in clay textures, which can make the seeding operation difficult because of the impact on the seeder gauge wheels. In contrast, dry weather conditions in spring make seeder performance depend on soil moisture under irrigation systems, so that soil tenacity does not compromise seeder furrow openers.

Because good germination conditions for cereal crops depend on several characteristics of the seedbed environment and the sowing depth (Alessi and Power 1971; Mahdi et al. 1998), the latter related to soil opener interaction (Tessier et al. 1991), seed placement close to optimum sowing depth must be guaranteed, in order to maximise potential maize yield. Canakci et al. (2009) and Fancelli (2000) showed that maize crop seed must be placed at the appropriate depth to generate uniform plants. Depending on soil texture and moisture, Fancelli (2000) suggested that maize seed depth placement should be between 30 and $50 \mathrm{~mm}$ in clay soils and 40 and $60 \mathrm{~mm}$ in sandy soils. Placements shallower than $30 \mathrm{~mm}$ increase the risk of the seedbed drying, especially in sandy or loam textures, and deeper mesocotyl elongation can be halted by a superficial soil crust. Seeder distribution can be evaluated in the longitudinal and vertical planes. The vertical plane is specified by the seeding depth (Karayel and Özmerzi 2008).

Conventional criteria for examining the vertical seed distribution of furrow openers has been through the use of mean standard deviation or coefficient of variation of sowing depth. Considering the influence of the seeding operation on maize crop yield, Liu et al. (2004) demonstrated that there is a higher correlation between seed emergence uniformity and vertical seeder distribution than with horizontal distribution (Karayel and Özmerzi 2008).

In tillage systems, Neményi et al. (2006) proved that force mapping can be an effective tool for marking out within-field management zones or areas where the actual physical conditions of the soil may have a limiting effect on yield. Thus, different sensor technologies have been used to study machinery depth control performance; a load cell and a circular potentiometer to control tillage depth (Gorucu et al. 2001), load cells and sets of strain gauges to measure the load applied during tillage (Adamchuk et al. 2004), ultrasonic and linear displacement to control manure injection depth and regulate seeding depth (Saeys et al. 2007; Marlowe et al. 2009). The current possibilities include a variety of sensors such as load cells mounted on the depth control spring and linear variable differential transformers (LVDT) or transducers for determining the angular or vertical displacement of the seeding arms.

The most common depth control device used in conventional no-tillage seeders is the combination of a side gauge wheel activated by a spring-loaded or hydraulic system with press wheels. Carvalho (2001) classified the different no-till seeders, equipped with passive depth control mechanisms based on their furrow opener type and their ability to handle different physical conditions of the soil. Under these conditions, unless there is a new calibration set up, initial conditions remain constant, regardless of the physical conditions, texture, moisture or surface residue of the soil.

Although different active depth control mechanisms have recently been patented, conventional seeders are still preferred in Portugal, probably due to their commercial cost and mechanical simplicity. So the aim of this study was to evaluate the vertical distribution performance in conventional no-till seeders and the spatial variability of seed depth placement along the plots in non-controlled trials made under farmer conditions in the 
Alentejo region. The correlation between seed depth placement and some vegetative and growth characteristics of maize were evaluated.

\section{Materials and methods}

Tests were conducted over a period of 3 years (2010, 2011 and 2012) using conventional no-till seeders in three different fields at private farms in Alentejo (Fig. 1).

According to the FAO classification, the soil was Fluvisol in 2010, Luvisol in 2011 and a Cambisol in 2012, which corresponds to a homogeneous area of loam, clay and clay loam texture, respectively, sampled at a depth of $0-100 \mathrm{~mm}$. Average values for texture, organic matter in soil, crop residue, $\mathrm{pH}$, phosphorous, potassium, bulk density and gravimetric moisture are shown in Table 1.

Texture was determined by the Bouyoucos hydrometer method (Bouyoucos 1962); volumetric moisture content was determined following the protocol described by Gardner (1986); organic matter by the Walkley-Black protocol (Walkley and Black 1934); $\mathrm{pH}$ by a potentiometric method using a 1:2.5 dilution of soil to water and phosphorous and potassium by the Egner-Riehm methodology (Egner and Riehm 1955). Bulk density samples were taken with a $50 \mathrm{~mm}$ diameter ring and determined by dividing the weight of soil dried at $105^{\circ} \mathrm{C}$ for $48 \mathrm{~h}$ by the mass of water that would occupy the volume of the ring. In 2010, field plot management included set-aside. In 2011 and 2012, although maize was grown in monoculture, since 2004 field management has included traditional crop rotation with winter wheat (Triticum aestivum L.) and maize (Zea mays L.) under no-till conditions.

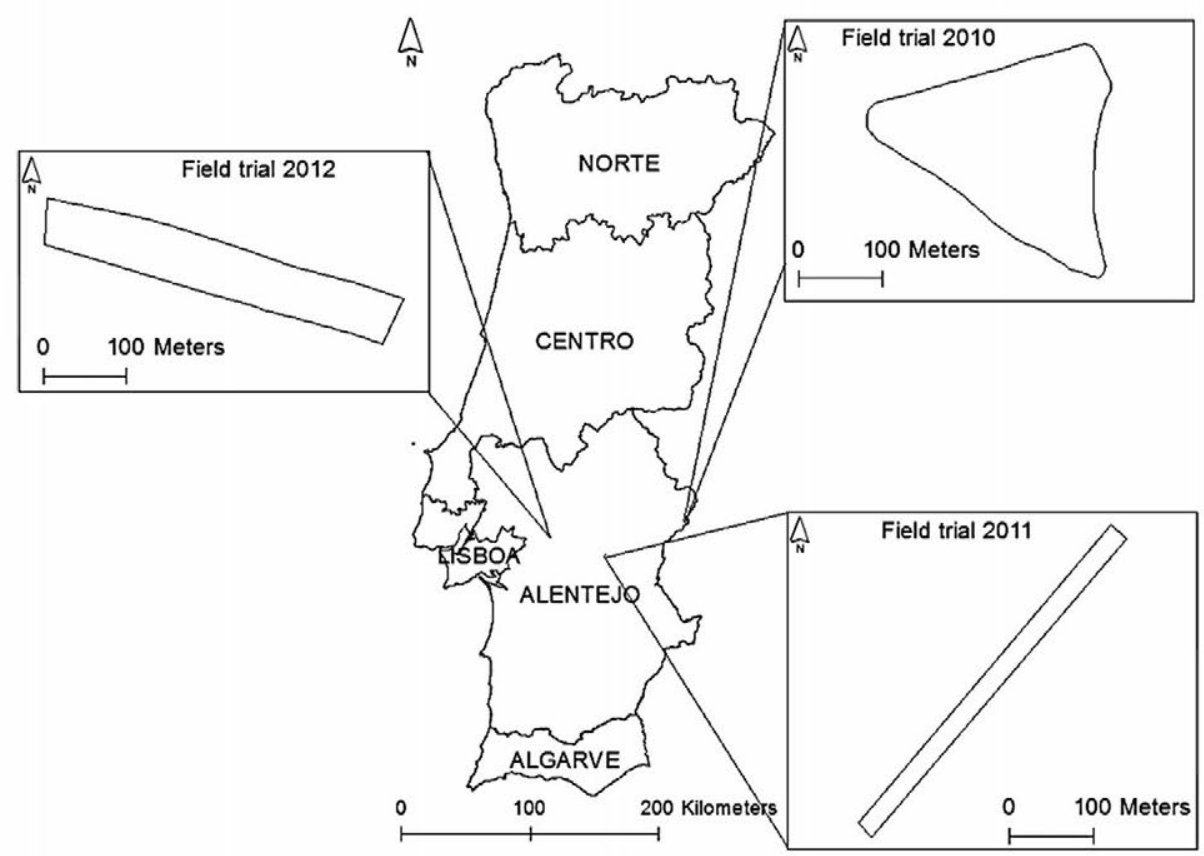

Fig. 1 Location of the three experimental fields in Alentejo region in 2010, 2011, 2012 
Table 1 Initial conditions and soil characteristics in the three trial fields

\begin{tabular}{|c|c|c|c|}
\hline & 2010 & 2011 & 2012 \\
\hline Local co-ordinates & $\begin{array}{c}38^{\circ} 53^{\prime} 47.52^{\prime \prime} \mathrm{N} \\
7^{\circ} 2^{\prime} 53.86^{\prime \prime} \mathrm{W}\end{array}$ & $\begin{array}{l}38^{\circ} 38^{\prime} 51.25^{\prime \prime} \mathrm{N} \\
7^{\circ} 46^{\prime} 55^{\prime \prime}, 55 \mathrm{~W}\end{array}$ & $\begin{array}{r}38^{\circ} 47^{\prime} 17^{\prime \prime} \mathrm{N}, \\
8^{\circ} 17^{\prime} 44^{\prime \prime} \mathrm{O}\end{array}$ \\
\hline Field area (ha) & 4.16 & 1.1 & 2.5 \\
\hline Seeding date & 15th June & 21st May & 14th May \\
\hline Previous crop & Set-aside & Maize & Maize \\
\hline FAO soil classification & Fluvisol & Luvisol & Cambisol \\
\hline Texture $(0-100 \mathrm{~mm})$ & Loam & Clay & Clay loam \\
\hline $\mathrm{pH}$ & 6.2 & 6.2 & 6.1 \\
\hline $\begin{array}{l}\text { Soil organic matter } \\
\text { content }(\%)\end{array}$ & 1.3 & 2.9 & 2.6 \\
\hline $\begin{array}{l}\text { Crop residue } \\
\left(\mathrm{g} \text { dry matter } \mathrm{m}^{-2}\right)\end{array}$ & 255 & 2010 & 2340 \\
\hline $\begin{array}{l}\text { Assimilable phosphorus } \\
\qquad\left(\mathrm{mg} \mathrm{P}_{2} \mathrm{O}_{5} \mathrm{~kg}^{-1}\right)\end{array}$ & 203 & 222 & 200 \\
\hline $\begin{array}{l}\text { Assimilable potassium } \\
\qquad\left(\mathrm{mg} \mathrm{K}_{2} \mathrm{O} \mathrm{kg}^{-1}\right)\end{array}$ & 200 & 222 & 198 \\
\hline Bulk density $\left(\mathrm{g} \mathrm{cm}^{-3}\right)$ & 1.53 & 1.4 & 1.45 \\
\hline Soil moisture content $(\%)$ & 5.21 & 12.5 & 11.3 \\
\hline
\end{tabular}

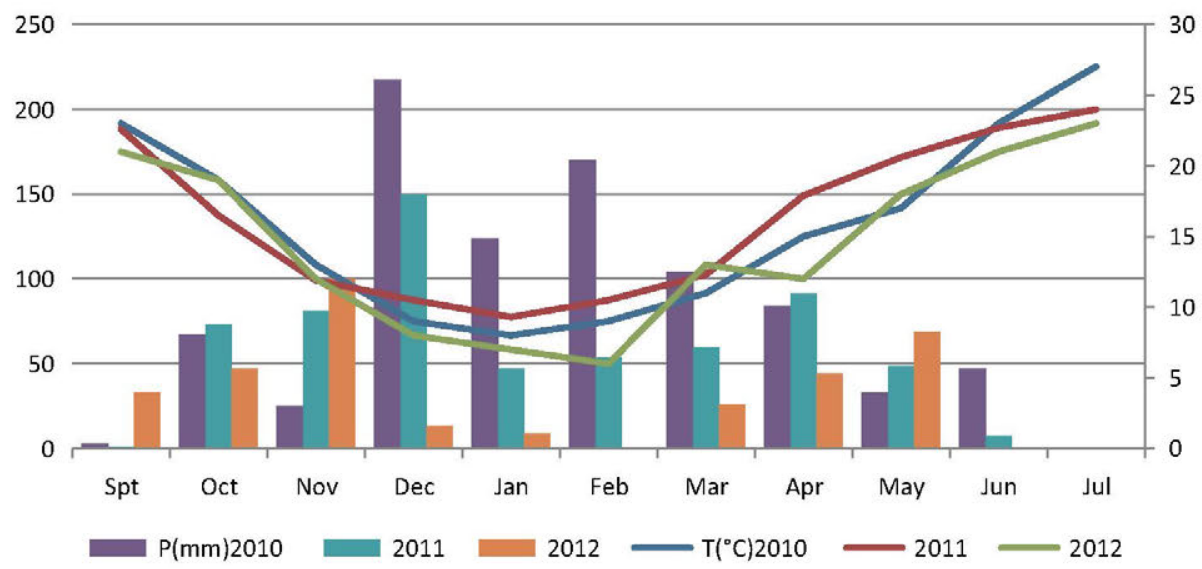

Fig. 2 Average temperature $\left({ }^{\circ} \mathrm{C}\right)$ and monthly rainfall $(\mathrm{mm})$ data for the 3 years $2010,2011,2012$

The climate is Mediterranean. Figure 2 shows the local temperature and precipitation data over the 3 years in trial from the Plant Research Institute (INIAV) in Elvas, located next to the 2010 and 2011 trials and $80 \mathrm{~km}$ far from the 2012 experimental site.

The corn seed used was FAO 400 hybrid seeds for grain. The maize crop was irrigated by a drip irrigation system in 2010 and by a centre pivot irrigation system in the 2011 and 2012 trials. The previous crops were a forage cereal graminea in 2010 and maize in both 2011 and 2012. 
Sowing operations were preceded by the application of a glyphosate-based herbicide. In 2011 and $2012,7 \mathrm{~mm}$ of water was applied at the time of sowing. The no-till seeders used were double disc furrow openers equipped with pantographic seed rows, independent drive wheels and a guillotine fertilizer opener. In all seeders, a mechanical press control was set by the tension of a spring system calibrated by the operator at the beginning of the operations and following the operator manual instructions for calibrations. The specific setup characteristics and calibrations are listed in Table 2. The seeders (Semeato, models SSE $5 / 6$ and SPE06, Passo Fundo, Brazil) were towed by $80 \mathrm{~kW}$ power tractors (Fig. 3).

In 2010, the seed depth placement and linear seedling down force were measured. To do this, an arm of the seeder was assembled with a LVDT sensor (Sensorex, model SX20MECR050, Garden Grove, USA) and a load cell (Lorenz Messtechnik GmbH, model K-2529, Alfdorf, Germany) (Fig. 4). A datalogger (Datataker, model DT80, Scoresby, Australia) was used for receiving and recording the values registered by the sensors and two GPS receivers, (Garmin model HVS, Kansas City, USA; and Arvatec, model Arvanav2, Rescaldina, Italy) were installed in the tractor cab in order to georeference the sensor data and measure the forward speed. A total of 10418 points were georeferenced; representing approximately 2500 samples ha ${ }^{-1}$.

The experimental design (Fig. 5) considered several seeder runs with a working length of $6 \mathrm{~m}$. The distance between the instrumented lines was either 0.75 or $12 \mathrm{~m}$, considering the seeder turns at each run so that geostatistical analysis could compare autocorrelations at smaller and larger distances.

Considering the topographic uniformity of the field, 14 and 30 randomised points were georeferenced, in 2011 and 2012, respectively, with a portable Magellan receiver (model Mobile Mapper CX, Santa Clara, USA), with differential correction signal (DGPS), providing a position accuracy of $0.15-0.20 \mathrm{~m}$. Soil resistance to penetration, seed depth placement and plant population were measured for each point. Throughout the trial, soil resistance was measured over a $0-50 \mathrm{~mm}$ depth using a manual Dickey John field penetrometer (model Soil Compaction Tester, Minneapolis, USA) with a $12.7 \mathrm{~mm}$ outside diameter tip and a $35^{\circ}$ apex angle, as recommended by the American Society of Agricultural Engineers (ASAE) as the standard measuring device for characterising the penetration resistance of soils (ASAE 1999). In each located point, data represented the average of four measurements. The methodology of Vamerali et al. (2006) and Neto et al. (2007) was used to estimate seed depth placement, by measuring the mesocotyl length of four sampled plants. Plant population was estimated by mean emergence time (MET) and percentage of emerged seedlings (PE) using Eqs. (1) and (2) (Bilbro and Wanjura 1982):

Table 2 Seeders characteristics and calibrations

\begin{tabular}{llll}
\hline & 2010 & 2011 & 2012 \\
\hline Seeder model & Semeato SSE 5/6 & Semeato SPE06 & Semeato SPE06 \\
Number of rows/row spacing (m) & $4 / 0.75$ & $4 / 0.75$ & $4 / 0.75$ \\
Depth control mechanism & Side gauge wheel and press wheels & \\
Seed depth set up (mm) & 30 & 30 & 50 \\
Average forward speed $\left(\mathrm{km} \mathrm{h}^{-1}\right)$ & 3 & 4 and 6 & 4 \\
Seeding rate (seeds/ha) & 70000 & 85000 & 80000 \\
Weight $(\mathrm{kg})$ & 2650 & & \\
\hline
\end{tabular}



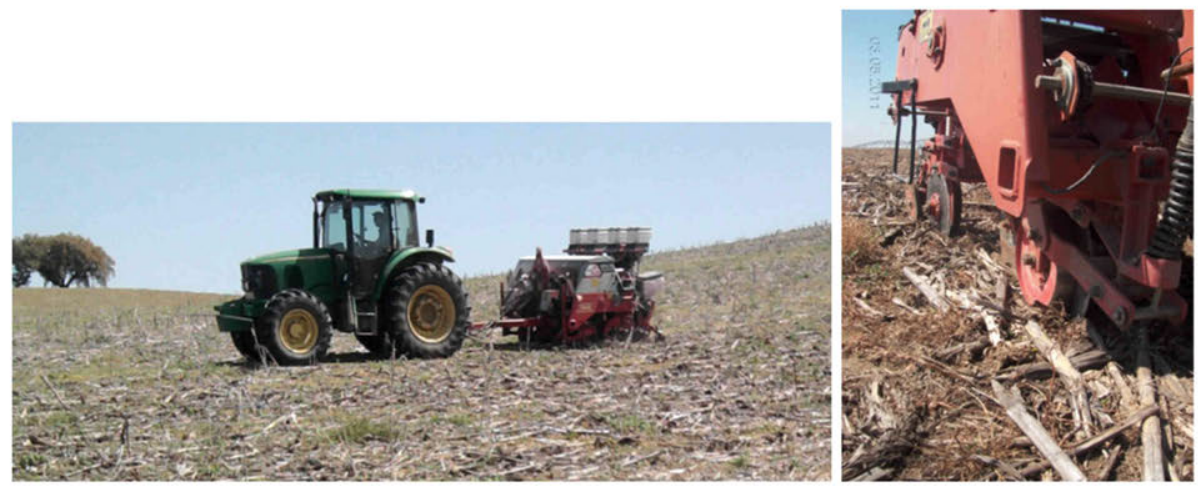

Fig. 3 Left double disc furrow opener seeder and tractor during sowing operation in 2011 and 2012 trials and, right side gauge wheel depth control
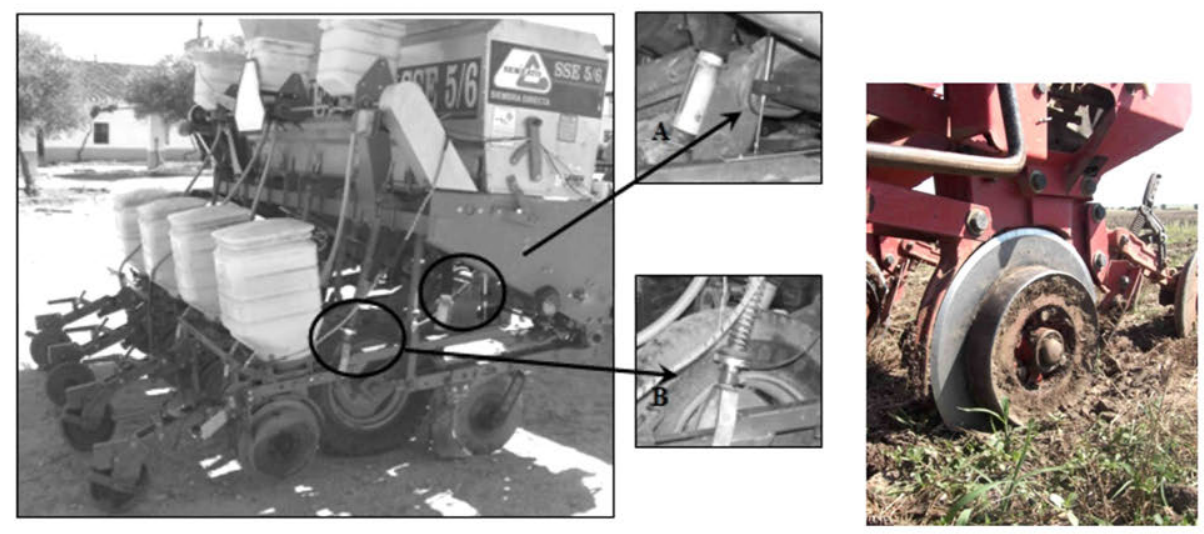

Fig. 4 LVDT $(A)$ and load cell $(B)$ sensors assembled on the seeder arm and side gauge wheel for depth control in 2010 trial

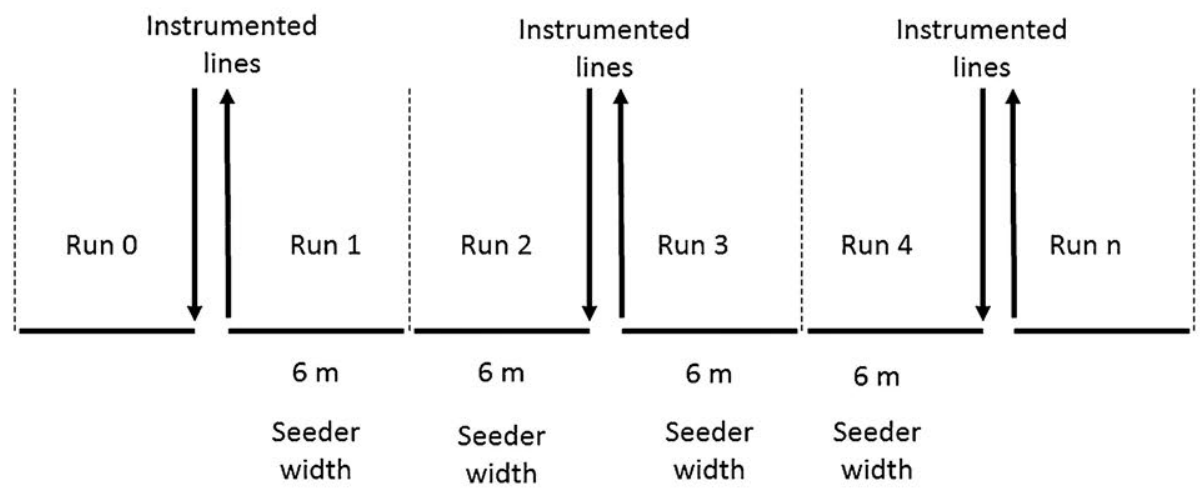

Fig. 5 Seeder runs scheme of the experimental design in 2010 trial 


$$
\begin{gathered}
\text { MET }=\frac{N 1 D 1+N 2 D 2+\cdots+N n D n}{N 1+N 2+\cdots+N n}, \\
\mathrm{PE}=\left(\frac{\text { total emerged seedling per metre }}{\text { number of seeds planted per metre }}\right) \times 100,
\end{gathered}
$$

where $N$ is the number of seedlings that had emerged since the previous counting and $D$ is the number of post-planting days. In 2011, two forward speeds of 4 and $6 \mathrm{~km} \mathrm{~h}^{-1}$ were used.

In 2012, a week after crop emergence, a selective herbicide for broadleaf weeds and grass was applied, and aerial photos of the georeferenced field were taken using an RGB camera Panasonic (model Lumix DC Vario 10.1 Mpixel CCD, Kadoma, Japan) assembled in an unmanned aerial vehicle flying at an approximate altitude of $500 \mathrm{~m}$ with a spatial resolution of $50 \mathrm{~mm}$. On a $5 \times 5 \mathrm{~m}$ square grid, the crop cover percentage was determined from the vegetative fraction, using the excess green technique (Meyer et al. 1999). With this technique, an image of green prevalence is generated, and the vegetation fraction is obtained using the ratio of the number of green pixels to the total number of the pixels in the image. Parameters were described using the mean standard deviation, coefficient of variation and correlation values. To determine the influence of soil resistance and seed depth placement, the collected data were subjected to analysis of variance using Statistica 6.0 software (StatSoft ${ }^{\circledR}$, Tulsa, USA). In 2010, spatial variability maps for the seeder down force and seed depth were created using ordinary kriging interpolation and ArcView software, version 9.0 (Redlands, USA) Given the dimensions of the plots in 2010 and 2011, spatial variability was demonstrated by a graphical representation of the average and standard deviation values of the parameters under study grouped by their neighbouring positions.

\section{Results}

The data for the 2010 trial are displayed in Table 3 and for the 2011 and 2012 trials in Table 4.

The ratios between soil mechanical resistance and seed depth placement for 2011 and 2012 trials are shown in Fig. 6. Seed depth placement, MET and PE seedlings were analysed to determine significant differences in the variability of the parameters and Pearson's correlation values of seed depth placement with mean emergence time and percentage of emergence are shown in Table 5.

Figure 7 shows spatial variability maps and variograms of seed depth and load cell down force, for the 2010 trial.

Table 3 Mean, standard deviation, coefficient of variation and correlation data for the seeder down force and estimated seed depth in the 2010 trial

\begin{tabular}{llllllll}
\hline Forward speed $\left(\mathrm{km} \mathrm{h}^{-1}\right)$ & \multicolumn{2}{l}{ Seeder down force $(\mathrm{N})$} & & & Seed depth $(\mathrm{mm})$ & $\mathrm{r}$ \\
\cline { 2 - 3 } & $\mathrm{X} \pm \mathrm{SD}$ & $\mathrm{CV}$ & & $\mathrm{X} \pm \mathrm{SD}$ & $\mathrm{CV}$ & \\
\hline 2010 & $961.43 \pm 241.05$ & 25.07 & & $23.61 \pm 7.57$ & 32.08 & 0.34 \\
\hline
\end{tabular}




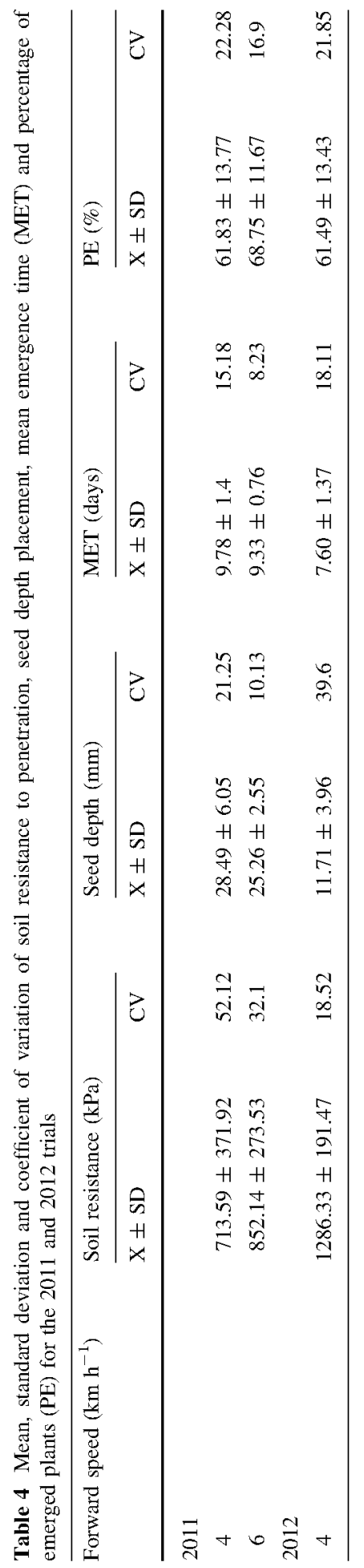




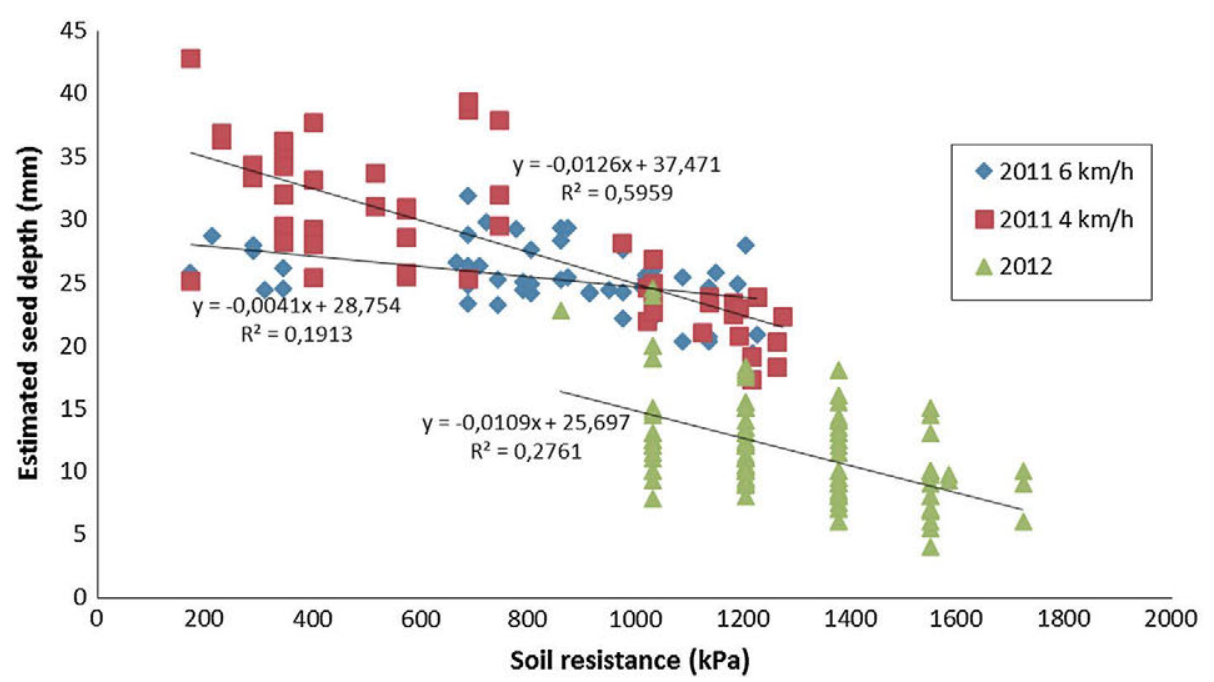

Fig. 6 Ratio between seed depth $(\mathrm{mm})$ and soil resistance to penetration $(\mathrm{kPa})$ in the experimental fields in 2011 and 2012 considering two forward speeds

Table 5 Pearson's correlations for seed depth placement, mean emergence time (MET), and percentage of emergence (PE) for 2011 and 2012 trials at $4 \mathrm{~km} \mathrm{~h}^{-1}$

\begin{tabular}{llll}
\hline & Seed depth & MET & PE \\
\hline Seed depth & 1 & $0.723^{* * * *}$ & $0.196^{*}$ \\
MET & & 1 & $0.262^{* *}$ \\
PE & & & 1 \\
\hline
\end{tabular}

Correlations are presented with level of significance of $* \mathrm{p}<0.05, * * \mathrm{p}<0.01$ and $* * * \mathrm{p}<0.001$

Figure 8 shows the spatial variability of the average and standard deviation values of grouped points in seven neighbouring areas along the plots for the 2011 trial.

Figure 9 shows the average and standard deviation values of grouped points in five neighbouring areas along the plot for seed depth placement and soil resistance for the 2012 trial.

Although the average value of soil moisture was $11.3 \%$, due to agronomic moisture conditions to crop germination, two main areas were identified, below $8 \%$ (area A) and above $8 \%$ (area B). The influence of the average values of soil moisture content was determined for the main areas with seed depth below and above $10 \mathrm{~mm}$. The differences in seed depth placement are represented in the box-plot diagram in Fig. 10.

Figure 11 shows the PE and MET variability along the plot following the same methodology described above and a green spectral band image after crop emergence.

\section{Discussion}

In 2010, it was expected that the increasing down force would also increase the estimated depth. However, high coefficients of variation were observed of $25.03 \%$ for down force and $32.08 \%$ for sowing depth. Despite a positive ratio between the two parameters, the 

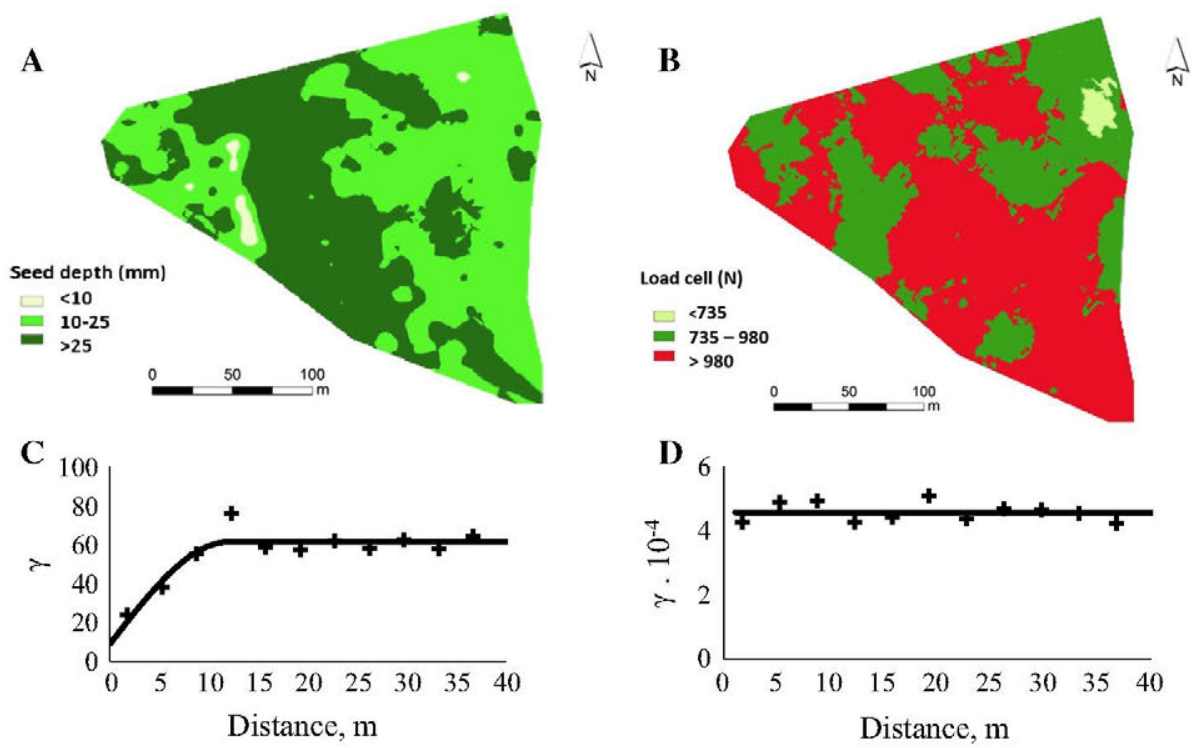

Fig. 72010 spatial variability and spatial structure: a, c seed depth; b, d seeder down force

correlation was very low. Spatial correlation to seed depth was observed for a range of $12 \mathrm{~m}$ (Fig. 7c) by adjusting the variogram to a spherical model. In contrast, there was no autocorrelation to the seeder down force parameter as can be seen on Fig. 7d, perhaps due to the spring system tension control limits, initially calibrated by the operator, that were not adjusted to the real soil conditions. The last is a key issue related to the passive depth control and probably surmountable with a dynamic depth control system. Figure $7 \mathrm{a}, \mathrm{b}$ show that along and across the crop presents a certain heterogeneity.

These results are probably due to dryness and some soil stone content observed during the trial, thus also affecting seed depth spatial variability. Considering that this field was managed using drip irrigation, soil moisture content at the sowing date depended on natural rainfall, which was low at the time. Under these conditions, the seeder had difficulty reaching the appropriate depth, as shown by the high coefficient of variation observed. Seed depth placement values closer to the calibration set of the seeder (in the class over $25 \mathrm{~mm}$ ) represented only $37 \%$ of the plot.

In 2011 and 2012, the relationship between soil mechanical resistance and seed depth placement as shown by Garrido et al. (2011), shows that there was always a negative correlation between the parameters (Fig. 6). Spatial variability along the plots, Fig. 8, shows that the lowest seed depth placement values are related to the areas of higher soil mechanical resistance. This is somewhat consistent with Vaz et al. (2011), who demonstrated that penetration resistance was lowest for very wet soils and that it increased with clay content. The highest influence of soil mechanical resistance on seed depth associated with a coefficient of determination $\left(\mathrm{R}^{2}\right)$ value of 0.59 (Fig. 6) was demonstrated in 2011 when working at $4 \mathrm{~km} \mathrm{~h}^{-1}$. The best seeding uniformity was achieved by increasing the forward speed from 4 to $6 \mathrm{~km} \mathrm{~h}^{-1}$, demonstrated by the lowest coefficient of variation of $10.13 \%$ (Table 4). In this plot, not only the adjusted forward speed contributed to such a coefficient of variation but also probably a more consistent value of soil resistance and so a 
A

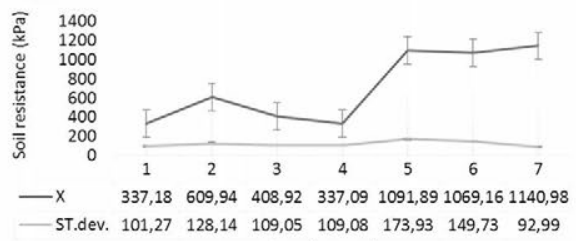
Georeferenced areas

$-\mathrm{X} \longrightarrow \mathrm{ST} . \mathrm{dev}$.

B

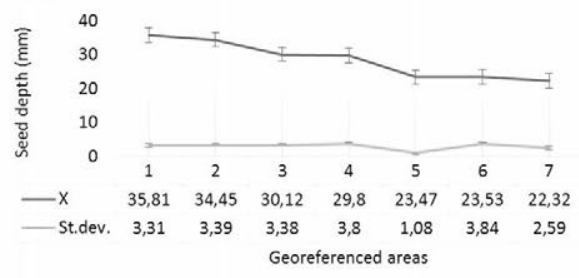

$-\mathrm{X} \longrightarrow$ St.dev.
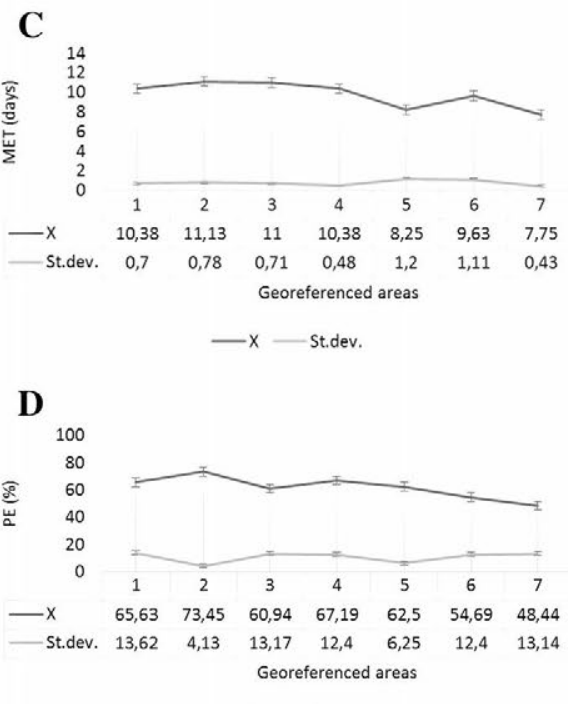

$\mathbf{E}$

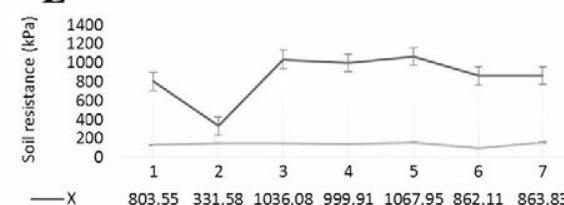
$\begin{array}{llllllll}\text {-St.dev. } & 129,04 & 146,38 & 145,63 & 137,78 & 157,04 & 101,81 & 159,02\end{array}$ Georeferenced areas

$-\mathrm{X} \longrightarrow$ St.dev.

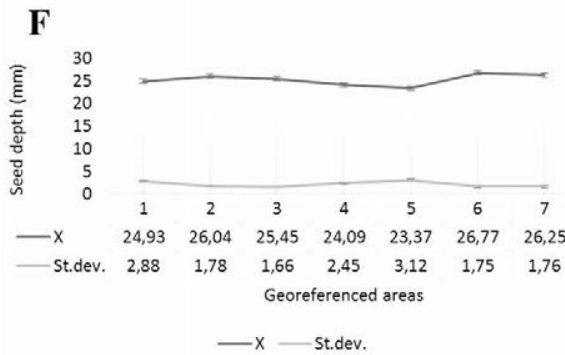

\section{G}

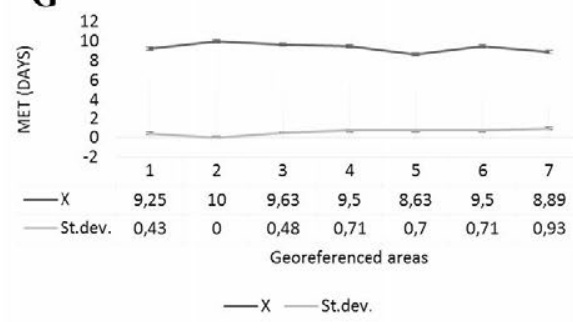

H

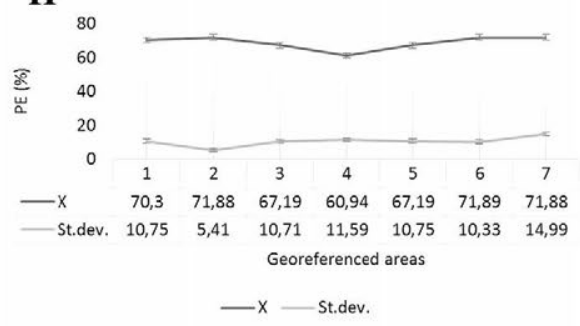

Fig. 8 Spatial variability representation along the plots in 2011 for soil resistance to penetration (a), seed depth placement (b), MET (c) and PE (d) for $4 \mathrm{~km} \mathrm{~h}^{-1}$ and soil resistance to penetration (e), seed depth placement (f), MET (g) and PE (h) for $6 \mathrm{~km} \mathrm{~h}^{-1}$

better performance of the seeder. Considering the same forward speed of $4 \mathrm{~km} \mathrm{~h}^{-1}$ in both trials, 2011 and 2012, seed depth placement had a significant influence on MET and PE and as described by Valero et al. (2010) in direct seeding systems, the variability of the ground resistance and the residues of previous crops magnify the difficulties in seed placement and emergence, with sometimes dramatic consequences for crop productivity. Both fields were covered by a significant quantity of crop residues, 2010 and $2340 \mathrm{~g} \mathrm{~m}^{-2}$, respectively. 
A

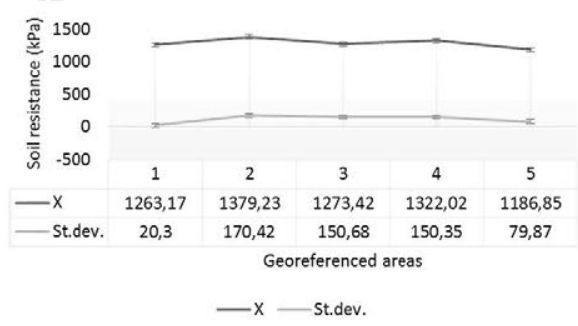

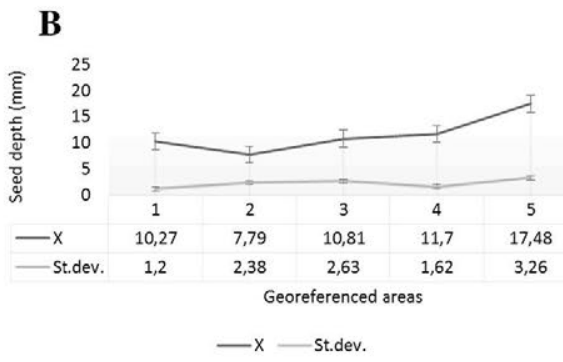

Fig. 9 Spatial variability representation along the plot in 2012 for seed depth placement (on the right) and soil resistance (on the left)

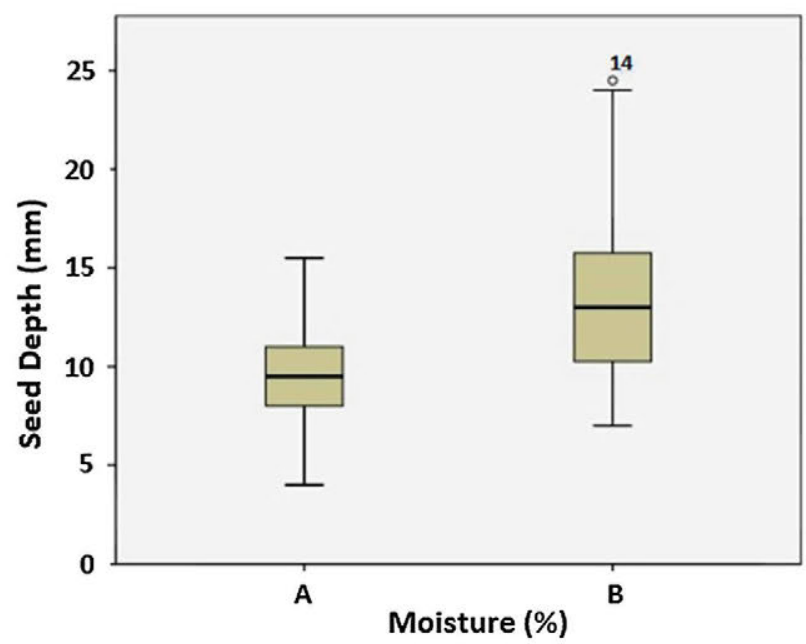

Fig. 10 Average values of seed depth placement and corresponding standard deviation for soil moisture content in 2012, with average values of 7.2 and $15.1 \%$, respectively, in trial field areas $A$ and $B$

In 2012, the results of the analysis show a shallow seed depth placement distribution, with an average value of $11.71 \mathrm{~mm}$ and the highest coefficient of variation of $39 \%$. Although seed depth placement was negatively correlated with soil resistance to penetration (Fig. 6), it was significantly influenced by the moisture content of the soil (Fig. 10) on the seeding date. Nevertheless, the relationship between soil moisture content and soil resistance is similar to that indicated by Gracia et al. (2012). In 2012, it was likely that under uniform conditions of soil moisture content and soil texture, the seeder would have been able to place the seeds at more regular intervals, to the initial depth control calibration. Also, the absence of a dynamic depth control may have contributed to the high coefficient of variation. Similar results were obtained by Neto et al. (2007) and Sunderman (1964). Nevertheless, these results are consistent with a preliminary trial by Conceição et al. (2012) who compared seeding uniformity in different tillage systems and found that seed depth placement was negatively correlated with soil resistance and significantly affected by the tillage system, particularly when comparing conventional tillage and minimum tillage with no-tillage. 

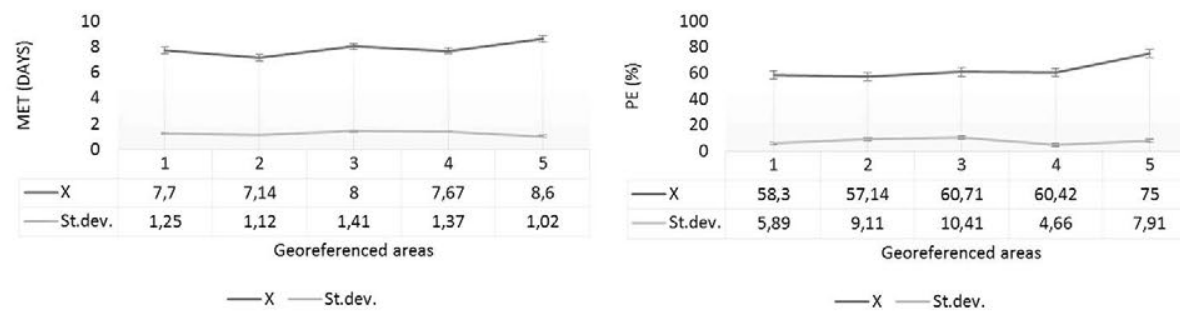

$1: 2000$

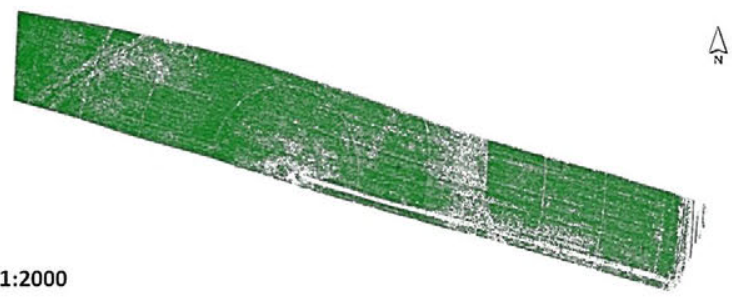

Fig. 11 MET (above left), PE (above right) and green spectral band image (below) after crop emergence along the plot in 2012

The extreme values of soil moisture content observed in the 2012 trial field were probably due to incorrect irrigation by the centre pivot irrigation system at the time of seeding. The shortest MET was found in the shallowest area with 6.2 days and the longest was at the deepest points with 8.6 days. In both the 2011 and 2012 trials, Pearson's correlations show that seed depth was positively correlated with MET. This is consistent with Tolon-Becerra et al. (2011) and Özmerzi et al. (2002), who demonstrated that the shortest emergence time was obtained at the shallowest depths. According to Özmerzi et al. (2002), although adequate moisture can usually be found with increasing depth, the risk of soil mechanical impedance also increases with seeding depth, thereby affecting seeder distribution.

In this experiment, the best PE result was found in the deepest areas, probably due to the more stable soil moisture conditions, especially in 2012, because of the lowest mean value of seed depth and the best uniformity of seeder vertical distribution in 2011 at $6 \mathrm{~km} \mathrm{~h}^{-1}$ by the lowest coefficient of variation, $10.13 \%$ compared to $21.25 \%$. Comparing MET and $\mathrm{PE}$, both parameters are significantly positively correlated. Similar results were found by Abrecht (1989), when deep planting slowed emergence but increased seedling growth in maize. Considering that MET determines crop vegetative development (Fig. 11), it appears that areas with a higher percentage of maize crop coverage were located where these were at a more advanced stage of growth, corresponding to areas with shallower depths and earlier emergence despite the small number of plants.

\section{Conclusions}

The costs related to tillage operations and the importance of conservation farming systems, especially direct seeding, for improved soil quality are leading farmers to adopt no-tillage systems, particularly in areas identified as being at risk of erosion, such as Mediterranean countries like Portugal and Spain and regions like the Alentejo. Although the planters used 
are designed for direct seeding in undisturbed soil, the heterogeneity of soil and climatic conditions of the observed areas creates some operational difficulties which can be recorded and analysed through the use of precision agriculture technologies. As expected, soil conditions affect the quality of the sowing operation with respect to vertical distribution and hence the distribution uniformity of the seed depth placement.

In 2010, despite the positive trend between the seeder down force and estimated seed depth placement, it can be concluded that the low moisture content of the soil on the seeding date and the probable presence of some stones observed during the trial conditioned this correlation, leading to the high coefficients of variation that were observed for both parameters and thus hampering the operation conditions of the seeder.

In 2011 and 2012, there was a negative correlation between soil resistance and depth of seeding and, in 2012, soil texture and the extreme values of soil moisture observed significantly conditioned the main deep and shallow areas of seed depth. In both trials, the increase in seed depth was positively correlated with crop PE and MET. Except in 2011, when increasing the forward speed from 4 to $6 \mathrm{~km} \mathrm{~h}^{-1}$ doubled the uniformity of sowing depth with a coefficient of variation of $10.13 \%$, the value of the coefficient of variation was above $20 \%$. This suggests that the performance of seeders should be enhanced by improving the calibration system for depth control or precision tuning by the operator during operation, depending on the existing field conditions. Given the relevance for no tillage technology of the results, due to the observed different sowing conditions in each year, a more complete experiment should be carried out in larger areas to better understand spatial variability across fields.

Acknowledgments The authors would like to acknowledge the Alentejo Operating Unit of the Portuguese Department of Agriculture, and Antonio Perdigão and Pedro Vacas de Carvalho (the owners of the farms where the trials were carried out) for granting permission, as well as Area400 (http://area400.com/) for the remote sensing services provided.

Abrecht, D. G. (1989). No till crop establishment on red earth soils at Katherine, Northern Territory: Effect of sowing depth and firming wheel pressure on the establishment of cowpea, mung bean, soybean and maize. Australian Journal of Experimental Agriculture, 29(3), 397-402.

Adamchuk, V. I., Skotnikov, A. V., Speichinger, J. D., \& Kocher, M. F. (2004). Development of an instrumented deep-tillage implement for sensing of soil mechanical resistance. Transactions of the ASABE, 47(6), 1913-1919.

Agriculture and Consumer Protection Department, FAO. (2015). Conservation agriculture. http://www.fao. org/ag/ca/6c.html. Accessed 13 June 2015.

Alessi, J., \& Power, J. F. (1971). Corn emergence in relation to soil temperature and seedling depth. Agronomy Journal, 63, 717-719.

American Society of Agricultural Engineers (ASAE). (1999). Soil cone penetrometer. ASAE Standard S313.3. St. Joseph: American Society of Agricultural Engineers.

Basch, G., Barros, J. F. C., Calado, J. M. G., \& Brandão, L. M. C. (2008). The potential of no-till and residue to sequester carbon under rainfed Mediterranean conditions. In: Z. Lehocká, \& M. Klimeková, W. Sukkel (Eds.). In ECOMIT: Proceedings of the 5th international scientific conference on sustainable farming systems. Piešt'any, pp. 61-66.

Basso, B., Sartori, L., Bertocco, M., Cammarano, D., Martin, E., \& Grace, P. (2011). Economic and environmental evaluation of site-specific tillage in a maize crop in NE Italy. European Journal of Agronomy, 35, 82-83.

Bilbro, J. D., \& Wanjura, D. F. (1982). Soil crusts and cotton emergence relationships. Transactions of the ASAE, 25(4), 1484-1487. 
Borin, M., Menini, C., \& Sartori, L. (1997). Effects of tillage systems on energy and carbon balance in North-Eastern Italy. Soil and Tillage Research, 40, 209-226.

Bouyoucos, G. J. (1962). Hydrometer method improved for making particle size analysis of soils. Agronomy Journal, 54, 464-465.

Canakci, M., Karayel, D., Topakci, M., \& Koc, A. (2009). Performance of a no-till seeder under dry and wet soil conditions. Applied Engineering in Agriculture, 25, 459-465.

Carvalho, M. (2001). Manual de divulgação de sementeira directa e técnicas de mobilização mínima (No tillage and minimum tillage guide). Direcção-Geral de Desenvolvimento Rural, Lisboa, p. 55.

Carvalho, M. (2003). Contribuição da sementeira direta para o aumento da sustentabilidade dos sistemas de culturas arvenses (Contribution of direct seeding for increasing sustainability of crop systems). In: V. Barros \& J. Ramos (coord.), Agricultura sustentável ciclo de seminários, Lisboa. Instituto Nacional de Investigação Agrária (pp. 59-73).

Carvalho, M., \& Basch, G. (1994). Experiences with direct drilling in Portugal. In Proceedings of the ECWorkshop-I-experience with the applicability of no-tillage crop production in the West-European, Wissenschaflticher Fachverlag, pp. 105-110.

Carvalho, M., \& Basch, G. (1999). Efficient use of water in the southern region of Portugal: Agronomic aspects. Agricultural Water Management, 40, 275-281.

Conceição, L. A., Garrido, M., Valero, C., Dias, S., Barreiro, P., \& Freixial, R. (2012). Effects of different soil management practices on soil mechanic resistance and seed depth placement in a maize crop in Alentejo, Portugal. In Proceedings of the International Conference of Agricultural Engineering, CIGR Ageng 2012, Valencia, pp. C-937.

Derpsh, R., Friedrich, T., Kassam, A., \& Li, H. W. (2010). Current status of adoption of no-till farming in the world and some of its main benefits. International Journal of Agricultural and Biological Engineering, 3(1), 1-26.

Egner, H., \& Riehm, H. (1955). Die doppellactatmethode (The doublé lactate method). In T. R. Herman \& E. Kinkmann (Eds.), Die untersuchung von Boden Verbandes Deutscher Landwirtschaftlicher-Untersuchungs-und Forschungsanstalten (pp. 110-125). Radebeul: Methodenbuch I.

Fancelli, A. L. (2000). Crop physiology and basic aspects of management for high yield. In I. Santini \& A. L. Fancelli (Eds.), Maize crop: Management strategies for the south region (pp. 103-106). Guarapuava: Fundação Agrária de Pesquisa Agro-Pecuaria.

Gardner, W. H. (1986). Water content. In A. Klute, G. S. Campbell, R. D. Jackson, M. M. Mortland, \& D. R. Nielsen (Eds.), Methods of soil analyses. Part 1. Physical and mineralogical methods (pp. 493-541). Madison: Soil Science Society of America Inc.

Garrido, M., Conceição, L. A., Baguena, E. M., Valero, C., \& Barreiro, P. (2011). Evaluating the need for an active depth-control system for direct seeding in Portugal. In J. V. Stafford (Ed.), Proceedings of the 8th European Conference on Precision Agriculture (pp. 371-381). Wageningen: Wageningen Academic Publishers.

Gorucu, S., Khalilian, A., Han, Y. J., Dodd, R. B., Wolak, F. J., \& Keskin, M. (2001). Variable depth tillage based on geo-referenced soil compaction data in Coastal Plain region of South Carolina. St. Joseph: ASAE.

Govaerts, B., Sayre, K. D., Goudeseune, B., De Corte, P., \& Lichter, K. (2009). Conservation agriculture as a sustainable option for the central Mexican highlands. Soil \& Tillage Research, 103, 222-230.

Gracia, C., Alemany, E., \& Bautista, I. (2012). Relationship between compaction, moisture and penetration resistance in horticulture soil. In: Soil and Water Engineering Journal, Proceedings of the International Conference of Agricultural Engineering, CIGR Ageng 2012, Spain, pp. 0-913.

Instituto Nacional de Estatística (INE). (2011). Recenseamento agrícola 2009-análise dos principais resultados. Census of agriculture-main results of the year 2009. Lisboa: Instituto Nacional de Estatística, p. 60 .

Karayel, D., \& Özmerzi, A. (2008). Evaluation of three depth-control components on seed placement accuracy and emergence for a precision planter. Applied Engineering in Agriculture, 24(3), 271-276.

Kirkby, M. J., Jones, R. J. A., Irvine, B. J., Gobin, A., Govers, G., Cerdan, O., et al. (2004). Pan-European Soil Erosion Risk Assessment: The PESERA Map, Version 1 October 2003. Explanation of Special Publication Ispra 2004 No.73 (S.P.I.04.73). European Soil Bureau Research Report No.16, EUR 21176 , p. 18.

Kottek, M., Grieser, J., Beck, C., Rudolf, B., \& Rubel, F. (2006). World Map of the Köppen-Geiger climate classification updated. Meteorologische Zeitschrift, 15(3), 259-263.

Liu, W., Tollenar, M., Stewart, G., \& Deen, W. (2004). Response of corn grain yield to spatial and temporal variability in emergence. Crop Science, 44(3), 847-854. 
Madejón, E., Murillo, J. M., Moreno, F., López, M. V., Arrue, J. L., Alvaro-Fuentes, J., et al. (2009). Effect of long-term conservation tillage on soil biochemical properties in Mediterranean Spanish areas. Soil and Tillage Research, 105(1), 55-62.

Mahdi, L., Bell, C. J., \& Ryan, J. (1998). Establishment and yield of wheat (Triticum turgidum L.) after early sowing at various depths in a semi-arid Mediterranean environment. Field Crops Research, 58, $187-196$.

Marlowe, B., Takashi, K., Hiroshi, O., \& Yoichi, S. (2009). Active seed depth control for no-tillage systems. St Joseph: ASABE.

Meyer, G. E., Hindman, T. W., \& Lakshmi, K. (1999). Machine vision detection parameters for plant species identification. In: Meyer G. E. \& DeShazer J. A. (Eds.) Precision agriculture and biological quality. Proceedings of SPIE, Bellingham (pp. 327-335).

Neményi, M., Mesterhazi, P. A., \& Milics, G. (2006). An application of tillage force mapping as a cropping management tool. Biosystems Engineering, 94(3), 351-357.

Neto, P. H. W., Schimandeiro, A., Gimenez, L. M., Colet, M. J., \& Garbuio, P. W. (2007). Profundidade da deposição de semente de milho na região dos Campos Gerais, Paraná. (Seed depth placement of a maize crop in the region of Campos Gerais, Paraná). Engenharia Agricola, Jaboticabal, 27(3), 782-786.

Özmerzi, A., Karayel, D., \& Topacki, M. (2002). Effect of sowing depth on precision seeder uniformity. Biosystems Engineering, 82(2), 227-230.

Piorr, H. P. (2011). Experiences with the evaluation of agricultural practices for EU Agri-Environmental Indicators. OECD (pp. 9-12).

Sá, J. C. M. (2004). Adubação fosfatada no sistema de plantio direto (phosphorus fertilization in no-tillage system). In T. Yamada, \& S. R. S. Abdalla, (Eds.), Proceedings of the Conference on Phosphorus in Brazilian Agriculture (pp. 201-222). Piracicaba: Potafos.

Saeys, W., Engelen, K., Ramon, H., \& Anthonis, J. (2007). An automatic depth control system for shallow manure injection, part 1: Modelling of the depth control system. Biosystems Engineering, 98(2), 146-154.

Soane, B. D., Ball, B. C., Arvidsson, J., Basch, G., Moreno, F., \& Roger-Estrade, J. (2012). No-till in northern, western and south-western Europe: A review of problems and opportunities for crop production and the environment. Soil \& Tillage Research, 118, 66-87.

Serviço de Reconhecimento e Ordenamento Agrário (SROA). (1978). Carta de Solos (Soils Chart). In Atlas do Ambiente. Instituto do Ambiente: Lisboa. http://www.iambiente.pt/atlas/c_tiposolo.html Accessed 13 June 2015.

Sunderman, D. W. (1964). Seedling emergence of winter wheats and its association with depth of sowing, coleptile length under various conditions, and plant height. Agronomy Journal, 56(1), 23-25.

Tabatabaeefar, A., Emamzadeh, H., Varnamkhasti, M. G., Rahimizadeh, R., \& Karimi, M. (2009). Comparison of energy of tillage systems in wheat production. Energy, 34, 41-45.

Tessier, S., Hyde, G. M., Papendick, R. I., \& Saxton, K. E. (1991). No-till seeders effects on seed zone properties and wheat emergence. Transactions of the ASAE, 34(3), 733-739.

Tolon-Becerra, A., Tourn, M., Botta, G. F., \& Lastra-Bravo, X. (2011). Effects of different tillage regimes on soil compaction, maize (Zea mays L.) seedling emergence and yields in the eastern Argentinean Pampas region. Soil \& Tillage Research, 117, 184-190.

Uri, N. D. (2000). Perceptions on the use of no-till farming in production agriculture in the United States: An analysis of survey results. Agriculture, Ecosystems and Environment, 77, 263-266.

Ussiri, D. A. N., \& Lal, R. (2009). Long-term tillage effects on soil carbon storage and carbon dioxide emissions in continuous corn cropping system from an alfisol in Ohio. Soil \& Tillage Research, 104(1), $39-47$.

Ussiri, D. A. N., Lal, R., \& Jarecki, M. K. (2009). Nitrous oxide and methane emissions from long-term tillage under a continuous corn cropping system in Ohio. Soil and Tillage Research, 104(2), 247-255.

Valero, C., Navas, L. M., González, F., Gómez, J., Ruiz, G., Barreiro, P., et al. (2010). Ahorro y Eficiencia Energética en la Agricultura de Precisión (Savings and Power Efficiency in Precision Agriculture). Instituto para la Diversificación y Ahorro Energético de España (IDAE), en la serie de "Ahorro y Eficiencia Energética en la Agricultura". http://www.idae.es/uploads/documentos/documentos_10995_ AEE_Agr_Precision_AGR16_A2010_69054ba0.pdf. Accessed 13 June 2015.

Vamerali, T., Bertocco, M., \& Sartori, L. (2006). Effects of a new wide-sweep opener for no-till planter on seed zone properties and root establishment in maize (Zea mays L.): A comparison with double-disk opener. Soil \& Tillage Research, 89, 196-209.

Vaz, C., Manieri, J., Isabella, M., \& Tuller, M. (2011). Modelling and correction of soil penetration resistance for varying soil water content. Geoderma, 166, 92-101.

Walkley, A., \& Black, I. A. (1934). An examination of the Degtjareff method for determining soil organic matter, and a proposed modification of the chromic acid titration method. Soil Science, 37, 29-38. 